\title{
Growth and yield performance of soybean with the application of Bradyrhyzobium inoculant via furrow and seed
}

\section{Crescimento e desempenho produtivo de plantas de soja em função da aplicação de inoculante via sulco e em semente}

\author{
Santiel Alves Vieira Neto우 Fábio Ribeiro Pires²; João Carlos Madalão ${ }^{3 *}$; Douglas \\ Gomes Viana ${ }^{4}$; Carlos César Evangelista de Menezes ${ }^{5}$; Renato Lara de Assis ${ }^{6}$
}

\begin{abstract}
Given the high costs of agricultural production, especially due to the price of fertilisers, particularly nitrogen, the use of inoculants to supply nitrogen to soybean crops is a widely recommended practice. The objective of this study was to evaluate the feasibility of applying inoculants through seed and planting furrow in soil previously cultivated with soybean and Brazilian native "cerrado" biome soil under greenhouse conditions. Seven treatments were tested: 1) inoculation via seed (inoculant + fungicide + micronutrient), 2) treatment via seed (fungicide + micronutrient), 3) control (only seed), 4) inoculation via furrow-dose 1 (recommended dose), 5) inoculation via furrow-dose 2 (twice the recommended dose), 6) inoculation via furrow-dose 3 (three times the recommended dose) and 7) inoculation via furrow-dose $1+$ seed inoculation. We evaluated plant height, fresh and dry matter weight of the aerial part and nodules, number of total, viable and non-viable nodules, number of pods per plant and grain yield. Inoculation was more effective when used in cerrado soil, but soybean performance in treatments without inoculation was higher in previously cultivated soil. Application through furrow proved to be a viable practice due to the similarity of the results obtained with the traditional application by seed.
\end{abstract}

Key words: Soybean yield. Nodulation. Pods number.

\section{Resumo}

Diante dos custos da produção agrícola, consideravelmente elevados em função do preço dos fertilizantes e, particularmente, os nitrogenados, o uso de inoculantes, visando fornecimento de nitrogênio para a cultura da soja, tem sido uma tecnologia frequentemente recomendada para viabilizar a produção. Objetivou-se com este trabalho avaliar a viabilidade da aplicação de inoculantes via semente e sulco de semeadura, em solo já cultivado e em solo de cerrado nativo com a cultura da soja. O ensaio foi realizado em casa-de-vegetação, utilizando solo de cerrado, sem cultivo anterior, e solo com histórico de cultivo de soja. Foram testados sete tratamentos: 1) inoculação via semente (inoculante + fungicida + micronutriente), 2) tratamento via semente (fungicida + micronutriente), 3 ) testemunha (semente

Eng ${ }^{\circ}$ Agro , M.e, Produção Vegetal, Autônomo, Rio Verde, GO, Brasil. E-mail: santiel@gmail.com

2 Prof., Centro Universitário Norte do Espírito Santo, Universidade Federal do Espírito Santo, CEUNES/UFES, São Mateus, ES, Brasil. E-mail: pires.fr@gmail.com

3 Pós-Doutor, CEUNES/UFES, São Mateus, ES, Brasil. E-mail: joaocmad@gmail.com

4 Eng $^{\circ}$ Agr $^{\circ}$, Discente de Mestrado, CEUNES/UFES, São Mateus, ES, Brasil. E-mail: d13viana@gmail.com

5 Pesquisador, Cooperativa Agroindustrial dos Produtores Rurais do Sudoeste Goiano, Rio Verde, GO, Brasil. E-mail: carlosmenezes@comigo.com.br

6 Prof., Instituto Federal Goiano, IFGoiano, Campus Iporá, Iporá, GO, Brasil. E-mail: relassis@bol.com.br

* Author for correspondence

Received: Sept. 06, 2016 Approved: Nov. 21, 2016 
pura, sem tratamento), 4) via sulco-dose1 (dose recomendada), 5) sulco-dose2 (duas vezes a dose recomendada), 6) sulco-dose3 (três vezes a dose recomendada), e 7) sulco-dose1+ inoculação via semente. Foram avaliados altura de plantas; massa de matéria fresca e seca da parte aérea e nódulos; número de nódulos totais, viáveis e não-viáveis; número de vagens por planta e rendimento de grãos. A inoculação foi mais efetiva no incremento das variáveis analisadas quando utilizada no solo de cerrado, e o desempenho da soja nos tratamentos que não receberam inoculação foi melhor no solo já cultivado. A aplicação via sulco mostrou-se uma prática viável em razão da semelhança dos resultados obtidos com a aplicação tradicional, via semente.

Palavras-chave: Rendimento da soja. Nodulação. Número de vagens.

\section{Introduction}

In the current energetic conjuncture and global economic environment, the cost of agricultural production has been considerably increased due to the price of synthetic fertilisers, particularly nitrogenous ones. The energy used in the production of $50 \mathrm{~kg}$ of nitrogen fertiliser is equivalent to that provided by about $80 \mathrm{~L}$ of gasoline, an amount that is surpassed by the biological fixation in soybean (MASCARENHAS et al., 2003). The energy demand required to produce $1 \mathrm{~kg}$ of nitrogen fertiliser is about six times greater than needed to produce $1 \mathrm{~kg}$ of $\mathrm{P}$ or $\mathrm{K}$.

Nitrogen $(\mathrm{N})$ is a macronutrient that usually occurs in low concentrations in soils located in tropical regions such as Brazil, but accounts for $78 \%$ of the atmosphere, albeit in a form which is non-assimilable for plants (MASCARENHAS et al., 2003). However, the cultivation of various crops is of high importance in the tropics; e.g. for soybean, high yields can be obtained in such regions, given that the nutritional requirements of the cultures are met.

Biological nitrogen fixation (BNF) in Leguminosae is the association between specific bacteria and roots featuring a symbiotic interaction, constituting an essential source of $\mathrm{N}$ especially in soybean (RASCIO and ROCCA, 2008; MENDES et al., 2010; TERPOLILLI et al, 2012). The supply of $\mathrm{N}$-fertilizer to crops performing symbiotic fixation has been reduced to small amounts or omitted. However, this practice, particularly in the cultivation of soybean, bean, pea and other legumes, brought economic and environmental advantages for Brazil (MENDES et al., 2010).

In soybean cultivation, the use of inoculants containing bacteria of the genus Bradyrhizobium is a common technique (VIEIRA NETO et al., 2008a, 2008b; ALBAREDA et al., 2008; PREVOST et al., 2012.) to achieve high productivity of cerrado biome soils. The spread of this practice is based on the ratification of the low investment that requires the use of inoculants and significant economic return of this technology. The short-term results are reduced production costs and increased yields and profitability. As a long-term result, there is a residual increase of nitrogen that remains for subsequent cultivations, benefiting the production system. Moreover, inoculation is simple and convenient and indispensable for obtaining high yields (VIEIRA NETO et al., 2008a, 2008b; HUNGRIA et al., 2013).

In addition to the significant reduction in soybean production costs, another major benefit of inoculation with nitrogen fixing bacteria is the fact that this practice does not promote environmental pollution. About $50 \%$ of nitrogenous fertilisers applied to the soil are lost through denitrification and leaching, and volatilisation may cause problems related to the reduction of the ozone layer and eutrophication of rivers and lakes (increased nitrogen contents in the water), which may lead to uncontrolled algae growth and a subsequent reduction of oxygen, negatively impacting the aquatic fauna (HUANG et al., 2006; SUN et al., 2008; SIYAL, 2013; HUNGRIA et al., 2013). 
Although many details are available about the inoculation of soybean, the application method requires further elucidation. Typically, the inoculant is mixed with seeds before sowing, but little is known about new techniques such as the use of inoculant directly in the planting furrow, which may lead to optimal results. Furthermore, in soil in which soy had already been cultivated, the effect of inoculation might be smaller than in new areas. Thus, the available information does not consider the interference of the application method.

Given the above, the objective of this study was to evaluate the feasibility of inoculant application through seed and seed furrows in soil previously cultivated with soybean and in native cerrado soil.

\section{Material and Methods}

The experiment was performed in a greenhouse in vessels with a capacity of $8 \mathrm{dm}^{3}$ of soil. The experiment was a factorial $2 \times 7$ design and the A factor composed of two types of soil, both classified as clayey Oxisol (EMBRAPA, 2013): a) soil from an area of commercial soybean cultivation (over a period of 30 years) in the summer season (farming) and b) previously non-cultivated soil (native cerrado - NC). Factor B involved the inoculation of soybean (Table 1).

Table 1. Description of treatments applied to both soil types (native cerrado and previously cultivated soil).

\begin{tabular}{cl}
\hline Treatment & Description \\
\hline 1 & Seed (inoculant + fungicide + micronutrient) \\
2 & Seed (fungicide + micronutrient) \\
3 & Control (only seed) \\
4 & Furrow-dose 1 (recommended dose) \\
5 & Furrow-dose 2 (twice the recommended dose) \\
6 & Furrow-dose 3 (three times the recommended dose) \\
7 & Furrow (dose 1 in furrow) and Seed (Treatment 1) \\
\hline
\end{tabular}

The experiment was conducted in a random block design with eight replications. For each soil type, we used 56 vessels, totalling 112 experimental units. Soils were characterised chemically and physically (Table 2). 
Table 2. Physical and chemical attributes of the different soil types evaluated in the arable layer $(0-20 \mathrm{~cm})$.

\begin{tabular}{lcc}
\hline Attribute & Previously cultivated soil (tillage) & Soil NC* \\
\hline $\mathrm{pH}\left(\mathrm{CaCl}_{2}\right)$ & 5.26 & 4.02 \\
$\mathrm{Ca}\left(\mathrm{cmol}_{\mathrm{c}} \mathrm{dm}^{-3}\right)$ & 3.35 & 0.52 \\
$\mathrm{Mg}\left(\mathrm{cmol}_{\mathrm{c}} \mathrm{dm}^{-3}\right)$ & 1.24 & 0.15 \\
$\mathrm{Al}\left(\mathrm{cmol}_{\mathrm{c}} \mathrm{dm}^{-3}\right)$ & 0.05 & 0.75 \\
$\mathrm{H}+\mathrm{Al}\left(\mathrm{cmol}_{\mathrm{c}} \mathrm{dm}^{-3}\right)$ & 5.8 & 6.8 \\
$\mathrm{~K}\left(\mathrm{mg} \mathrm{dm}^{-3}\right)$ & 179 & 22 \\
$\mathrm{P}\left(\mathrm{mg} \mathrm{dm}^{-3}\right)$ & 30.43 & 0.19 \\
$\mathrm{O} . \mathrm{M} .\left(\mathrm{g} \mathrm{dm}^{-3}\right)$ & 40.97 & 39.83 \\
$\mathrm{CEC}\left(\mathrm{cmol}_{\mathrm{c}} \mathrm{dm}^{-3}\right)$ & 10.83 & 7.49 \\
$\mathrm{BS}\left(\mathrm{cmol}_{\mathrm{c}} \mathrm{dm}^{-3}\right)$ & 5.05 & 0.72 \\
$\mathrm{~V}(\%)$ & 46.67 & 9.66 \\
Sand $\left(\mathrm{g} \mathrm{kg}^{-1}\right)$ & 310 & 310 \\
Silte $\left(\mathrm{g} \mathrm{kg}^{-1}\right)$ & 170 & 150 \\
Clay $\left(\mathrm{g} \mathrm{kg}^{-1}\right)$ & 510 & 540 \\
\hline
\end{tabular}

For inoculation through seeds, we used peat (Glycimax ${ }^{\circledR)}$ as inoculant, including the strains SEMIA 587 and 5019, both belonging to the species Bradyrhyzobium elkanii, in a concentration of $3.0 \mathrm{x}$ 109 cells $\mathrm{g}^{-1}$. Ten grams of the inoculum were diluted in $30 \mathrm{ml}$ of sugar water ( $3 \mathrm{~g}$ sugar); the solution was applied to $5 \mathrm{~kg}$ of seeds and dried in the shade for 6 hours. After drying, sowing was performed.

For inoculation in the planting furrow, a liquid inoculum (Rhizomax ${ }^{\circledR}$ ) was used, containing the strains SEMIA 5079 and 5080, both belonging to the species Bradyrhyzobium japonicum, in a concentration of $2.0 \times 109$ cells $\mathrm{mL}^{-1}$. For this, $3.0 \mathrm{ml}$ of inoculum were diluted in $2 \mathrm{~L}$ of water for obtaining the recommended commercial dose (Treatment 4); $6.0 \mathrm{ml}$ inoculum were diluted in 2 $\mathrm{L}$ of water for treatment 5 (twice the recommended dose); $9.0 \mathrm{~mL}$ of inoculum were diluted in $2 \mathrm{~L}$ of water for treatment 6 (three times the recommended dose) and $3.0 \mathrm{ml}$ of inoculant were diluted in $2 \mathrm{~L}$ of water for treatment 7 (one dose of liquid inoculant in the furrow and one dose of peat inoculant in the seeds).
Prior to inoculation, the seeds used in all treatments, except in treatment 3 (only seed), were treated with the fungicides carbendazim $\left(30 \mathrm{~g} \mathrm{ha}^{-1}\right)$ and tiram $\left(70 \mathrm{~g} \mathrm{ha}^{-1}\right)$ and the micronutrients cobalt $(5$ $\left.\mathrm{g} \mathrm{ha}^{-1}\right)$ and molybdenum (25 $\left.\mathrm{g} \mathrm{ha}^{-1}\right)$.

According to the results of the soil analysis, there was a correction with dolomitic limestone, which remained incubated for 15 days under irrigation. After this period, we manually created a small furrow of a depth of $7 \mathrm{~cm}$ and a length of $25 \mathrm{~cm}$, corresponding to the internal diameter of the vessel, in the central part of each vessel. The furrows were fertilised according to the results of the chemical analysis, with amounts corresponding to 340 to $390 \mathrm{~kg} \mathrm{ha}^{-1}$ of the formula $02-20-18 \mathrm{~N}, \mathrm{P}$ and $\mathrm{K}$. Both soil types (cultivated and non-cultivated) were fertilised.

After fertilisation, the furrow was covered with a layer of about $4 \mathrm{~cm}$ of soil and six seeds were manually distributed per pot. While the furrow was still open, the inoculants were sprayed using a pressurised knapsack sprayer with $\mathrm{CO}_{2}$, coupled to a bar containing four spray nozzles of the fan type 
XR110.02, spaced at $0.5 \mathrm{~m}$, with a spray volume of $100 \mathrm{~L} \mathrm{ha}^{-1}$. Subsequently, the furrows were covered with a layer of about $3 \mathrm{~cm}$ of soil.

Within each block, the pots were distributed in four rows, spaced $0.50 \mathrm{~m}$ apart, equating to the spacing used in the field. Seven days after emergence (DAE), thinning was performed, leaving two plants per pot. Irrigation of the pots was performed when necessary to maintain field capacity.

Of each soil type, we collected four pots (four replicates) when the plants were at the beginning of the reproductive stage (50 DAE) for determination of nodule count (dry matter nodule, total number of nodules and number of viable and non-viable nodules), plant height, fresh weight and dry aerial part of the plant. The remaining four replicates were used to determine physiological maturation of plants, evaluating the production components in each pot, namely productivity (two plants), number of pods with one grain, number of pods with two grains and number of pods with three grains, as well as plant height and fresh and dry weight.

For determination of nodulation, we collected the pots containing plants with intact roots, placed them in plastic bags and transported them to the laboratory. After separation and washing of the roots, all nodules were removed and feasibility of nodules with a diameter equal or greater than $2 \mathrm{~mm}$ was evaluated.

Plant height was determined by measuring height from the soil surface to the top of the canopy; aerial parts were weighed before and after drying in a forced-air oven at $65^{\circ} \mathrm{C}$ until constant weight for determination of fresh and dry weight.

Data were submitted to analysis of variance and treatment means were compared by Duncan test at $5 \%$ probability.

\section{Results and Discussion}

The total number of nodules (TNN) was higher in pre-cultivated soil compared to treatment 3 (only seed) (Table 3). In all other treatments, micronutrients and fungicides were applied, of which the latter, when applied to the seeds, bacterial survival bacteria and hence nodulation, BNF and soybean yields are reduced (CAMPO et al., 2003; CAMPO et al., 2004; VIEIRA NETO et al., 2008b; PEREIRA et al., 2010; AHEMAD AND KHAN, 2011). Pereira et al. (2010) analysed the effect of fungicide treatment of soybean seeds and plants inoculated with Bradyrhizobium and found that treatment with carbendazim + thiram and thiabendazole + thiram reduced the number of nodules. 
Table 3. Total number of nodules (TNN), viable number of nodules (VNN), non-viable number of nodules (NNN) and dry mass of nodules (DMN) on soybeans grown in previously cultivated soil and native cerrado soil (NC) under different inoculation treatments.

\begin{tabular}{|c|c|c|c|c|c|c|c|c|}
\hline \multirow{2}{*}{ Treatment } & \multicolumn{2}{|l|}{ TNN } & \multicolumn{2}{|l|}{ VNN } & \multicolumn{2}{|l|}{ NNN } & \multicolumn{2}{|l|}{ DMN } \\
\hline & Tillage & $\mathrm{NC}$ & Tillage & $\mathrm{NC}$ & Tillage & $\mathrm{NC}$ & Tillage & $\mathrm{NC}$ \\
\hline $\begin{array}{l}\text { 1. Seed (inoculant }+ \text { fungicide } \\
+ \text { micronutrient) }\end{array}$ & $59 \mathrm{cA}$ & $62 \mathrm{cdA}$ & $54 \mathrm{dA}$ & $56 \mathrm{cdA}$ & $6 \mathrm{bA}$ & $6 \mathrm{bA}$ & $0.43 \mathrm{aA}$ & $0.42 \mathrm{aA}$ \\
\hline $\begin{array}{l}\text { 2. Seed (fungicide }+ \text { micronu- } \\
\text { trient) }\end{array}$ & $59 \mathrm{cA}$ & $48 \mathrm{dA}$ & $52 \mathrm{dA}$ & $42 \mathrm{dA}$ & $6 \mathrm{bA}$ & $6 \mathrm{bA}$ & $0.33 \mathrm{aA}$ & $0.56 \mathrm{aA}$ \\
\hline 3. Control (only seed) & $118 \mathrm{aA}$ & $78 \mathrm{bcB}$ & $106 \mathrm{aA}$ & $72 b c B$ & $6 \mathrm{bB}$ & $12 \mathrm{aA}$ & $0.36 \mathrm{aA}$ & $0.88 \mathrm{aA}$ \\
\hline $\begin{array}{l}\text { 4. Furrow-dose } 1 \text { (recommen- } \\
\text { ded dose) }\end{array}$ & $96 \mathrm{bA}$ & $110 \mathrm{aA}$ & $91 \mathrm{abA}$ & $96 \mathrm{aA}$ & $14 \mathrm{aA}$ & $8 \mathrm{bB}$ & $0.73 \mathrm{aA}$ & $0.80 \mathrm{aA}$ \\
\hline $\begin{array}{l}\text { 5. Furrow-dose } 2 \text { (twice the } \\
\text { recommended dose) }\end{array}$ & $76 \mathrm{bcA}$ & $62 \mathrm{cdA}$ & $69 \mathrm{cdA}$ & $56 \mathrm{cdA}$ & $6 \mathrm{bA}$ & $7 \mathrm{bA}$ & $0.43 \mathrm{aA}$ & $0.63 \mathrm{aA}$ \\
\hline $\begin{array}{l}\text { 6. Furrow-dose } 3 \text { (three times } \\
\text { the recommended dose) }\end{array}$ & $65 \mathrm{cB}$ & $93 \mathrm{abA}$ & $60 \mathrm{cdB}$ & 82abA & $11 \mathrm{aA}$ & $6 \mathrm{bB}$ & $0.60 \mathrm{aA}$ & $0.52 \mathrm{aA}$ \\
\hline $\begin{array}{l}\text { 7. Furrow (dose } 1 \text { in furrow) } \\
\text { and Seed (Treatment } 1 \text { ) }\end{array}$ & $88 \mathrm{baA}$ & 92abA & $79 \mathrm{bcA}$ & $80 \mathrm{abA}$ & $12 \mathrm{aA}$ & 9abA & $0.50 \mathrm{aA}$ & $0.63 \mathrm{aA}$ \\
\hline
\end{tabular}

Means followed by the same uppercase letters in the lines and lowercase letters in the columns, within each variable, did not differ significantly according to the Duncan test, at $5 \%$ probability of error.

Albino and Campo (2001) found that with the addition of increasing concentrations of various molybdenum sources to growth culture media of Bradyrhizobium, there was damage to the strains found in the composition of inoculants. Commercial products containing cobalt and molybdenum, typically used by farmers when applied in soybean seeds with the inoculant, reduce nodulation and, consequently, BNF potential (CAMPO et al., 1999; CAMPO; HUNGRIA, 2000). In addition, the soil might already contain strains of rhizobia that could inoculate soybeans.

In regards to BNF potential, treatment 4 (furrowdose 1) and treatment 7 (furrow + seed) did not differ and showed better results than treatment 1 (inoculant + fungicide + micronutrient via seed), treatment 2 (fungicide + micronutrient via seed) and treatment 6 (furrow-dose 3) (Table 3).

When analysing TNN of plants cultivated in the soil of the native cerrado (NC), values were higher in treatments 4, 6 and 7 compared to the other treatments, with the exception of treatment 3 (Table 3 ). Lowest values were obtained for treatment 2 , differing from those observed in the soil already cultivated with soybeans, but values did not differ between treatments 1 and 5 .

In terms of TNN values of plants cultivated in NC soil, considering absolute values, five of the seven treatments obtained higher values than those found in already cultivated soil, however, the difference was only statistically significant between treatment 3 (control) and 6 (furrow-dose 3) (Table 3). Note that if in the treatment soybeans 3 , the farming soil, which showed higher $\mathrm{TNN}$, soybean NC and treatment 6 were the opposite. This behaviour in treatment 3 can be explained by the fewer amount of Bradyrhizobium in NC soil, while in previously cultivated soil, the amounts of these microorganisms were higher. In treatment 6 , we applied a higher dose of the inoculant. As the initial number of Bradyrhizobium in NC soil was lower, soybean plants responded more significantly to the 
inoculant.

The viable number of nodules (VNN) followed a behaviour similar to $\mathrm{TNN}$; in the previously cultivated soil, highest values were obtained in treatments 3 and 4 (control and application via furrow-dose 1) and in the native cerrado soil in the treatments 4, 6 and 7 (Table 3). When comparing the two types of soils we noted that, similar to TNN, treatment 3 showed higher $\mathrm{VNN}$ values than $\mathrm{NC}$ soil; for treatment 6 , the opposite findings were observed. The number of non-viable nodules (NNN) (Table 3) followed a reverse behaviour observed for VNN values in treatments 3 and 6 ; however, in treatment 4, although there was no difference between the previously cultivated soil and NC in terms of VNN, NNN values were higher. Addition of Mo prior to inoculation can reduce the number of viable cells of Bradyrhizobium on soybean roots (ALBINO; CAMPO, 2001). It is likely that the combination of fertilisation in earlier years and the addition of molybdenum in this treatment reduced the viability of nodules. In the other treatments, there were no differences in terms of $\mathrm{VNN}$ and $\mathrm{NNN}$ between previously cultivated soil and NC. We found no differences between the different soil types in terms of dry matter of nodules (DMN, Table 3).

The averages obtained for fresh matter weight (FMW) in previously cultivated soil (Table 4) were higher for treatment 7 (furrow + seed), but did not differ between treatment 3 (control) and treatment 6 (furrow-dose 3). The same variable for solo NC, performed better in treatment 4 (furrow- dose 1), because it allowed greater accumulation of FMW in NC soil than in soil previously cultivated with soybeans. Soybeans cultivated in NC soil accumulated greater FMW in relation to soybeans in previously cultivated soil, possibly because in previously cultivated soil, the initial population of nitrogen-fixing organisms was smaller, leading to a greater FMW accumulation with the addition of Bradyrhizobium. The greater accumulation of FMW in treatment 4 (commercially recommended dose) is an indication that above the recommended doses, soybean plants do not respond to increased inoculation doses.

Mass of dry matter (MDM) showed a behaviour similar to FMW, albeit with less pronounced differences between inoculation forms (Table 4). Note that in treatments $2(+$ micronutrient fungicide in seed) and 4 (via furrow-dose 1), MDM production was higher when soybean was grown in soil without inoculation. In terms of furrow application, this result is in agreement with EMBRAPA (2013). However, in treatment 5 (furrow-dose 2), we observed the opposite effect, and the previously cultivated soil was superior to NC soil, possibly due to intrinsic soil fertility.

Plant height was not influenced by inoculation method and soil type (Table 4). This component is positively correlated with grain production and related with higher dry matter production because biomass production before flowering is a potential reserve for the formation of reproductive structures (DYBING, 1994). 
Table 4. Fresh matter, dry weight and height of soybean plants grown in previously cultivated and native cerrado soil (NC) under different inoculation treatments, evaluated during the flowering phase (50 DAE).

\begin{tabular}{lcccccc}
\hline \multirow{2}{*}{ Treatment } & \multicolumn{2}{c}{ Fresh matter } & \multicolumn{2}{c}{ Dry weight } & \multicolumn{2}{c}{ Height } \\
\cline { 2 - 7 } & Tillage & NC & Tillage & NC & Tillage & NC \\
\hline 1. Seed (inoculant + fungicide + micronutrient) & $28 \mathrm{bA}$ & $33.2 \mathrm{cdA}$ & $11 \mathrm{bA}$ & $12.6 \mathrm{cdA}$ & $51.6 \mathrm{aA}$ & $53.5 \mathrm{aA}$ \\
2. Seed (fungicide + micronutrient) & $30 \mathrm{bA}$ & $36.8 \mathrm{bcA}$ & $12 \mathrm{abB}$ & $15.4 \mathrm{abA}$ & $49.5 \mathrm{aA}$ & $53.0 \mathrm{aA}$ \\
3. Control (only seed) & $35 \mathrm{abA}$ & $41.4 \mathrm{bA}$ & $13 \mathrm{abA}$ & $14.3 \mathrm{cA}$ & $49.5 \mathrm{aA}$ & $51.3 \mathrm{aA}$ \\
4. Furrow-dose 1 (recommended dose) & $32 \mathrm{bB}$ & $57.3 \mathrm{aA}$ & $12 \mathrm{abB}$ & $17.2 \mathrm{aA}$ & $43.2 \mathrm{aA}$ & $51.3 \mathrm{aA}$ \\
5. Furrow-dose 2 (twice the recommended dose) & $31 \mathrm{bA}$ & $27.5 \mathrm{dA}$ & $13 \mathrm{abA}$ & $10.2 \mathrm{~dB}$ & $52.0 \mathrm{aA}$ & $50.5 \mathrm{aA}$ \\
6. Furrow-dose 3 (three times the recommended dose) & $34 \mathrm{abA}$ & $38.5 \mathrm{bcA}$ & $13 \mathrm{abA}$ & $14.3 \mathrm{bcA}$ & $50.6 \mathrm{aA}$ & $45.1 \mathrm{aA}$ \\
7. Furrow (dose 1 in furrow) and Seed (Treatment 1) & $41 \mathrm{aA}$ & $41.5 \mathrm{bA}$ & $15 \mathrm{aA}$ & $14.6 \mathrm{bcA}$ & $54.8 \mathrm{aA}$ & $43.0 \mathrm{aA}$ \\
\hline
\end{tabular}

Means followed by the same uppercase letters in the lines and lowercase letters in the columns, within each variable, did not differ significantly according to the Duncan test, at $5 \%$ probability of error.

In relation to the number of pods with one grain (NP1), two grains (NP2), three grains (NP3) and the total number of pods (TNP) as indicators of crop production (Table 5), we noted that in previously cultivated soil, there was no difference between treatments. In native cerrado soil, the NV1 was higher with the application in the furrow + seed (treatment 7). For NV2, the treatments fungicide + micronutrient in the seed, control and furrow-dose 2 differed of treatment 6 (dose-furrow 3), however, values were similar to those for the other treatments.
Treatment 1 had higher NP3 values in relation to treatments 6 and 7, with no difference between the remaining treatments. These results indicate that the use of inoculant in peat is more favourable for seed quality and final production. These results are in agreement with the findings by Carvalho et al. (2013), who state that the use of a plant regulator was significant for the increase of production parameters when compared to the control without inoculant. 
Table 5. Number of pods with one grain (NP1), two grains (NP2), three grains (NP3) and the total number of pods (TNP) of soybean plants grown in previously cultivated and native cerrado soil (NC) under different inoculation treatments, collected at the point of physiological maturation.

\begin{tabular}{lcccccccc}
\hline \multirow{2}{*}{ Treatment } & \multicolumn{2}{c}{ NP1 } & \multicolumn{2}{c}{ NP2 } & \multicolumn{2}{c}{ NP3 } & \multicolumn{2}{c}{ NPT } \\
\cline { 2 - 8 } & Tillage & NC & Tillage & NC & Tillage & NC & Tillage & NC \\
\hline $\begin{array}{l}\text { 1. Seed (inoculant + fungicide + } \\
\text { micronutrient) }\end{array}$ & $3.0 \mathrm{aA}$ & $4.3 \mathrm{bA}$ & $22.7 \mathrm{aA}$ & $22.3 \mathrm{abA}$ & $18.0 \mathrm{aA}$ & $27.3 \mathrm{aA}$ & $43.7 \mathrm{aA}$ & $54.0 \mathrm{aA}$ \\
$\begin{array}{l}\text { 2. Seed (fungicide + micronu- } \\
\text { trient) }\end{array}$ & $6.7 \mathrm{aA}$ & $5.3 \mathrm{bA}$ & $19.7 \mathrm{aB}$ & $29.3 \mathrm{aA}$ & $19.7 \mathrm{aA}$ & $16.5 \mathrm{abA}$ & $46.0 \mathrm{aA}$ & $51.0 \mathrm{aA}$ \\
$\begin{array}{l}\text { 3. Control (only seed) } \\
\begin{array}{l}\text { 4. Furrow-dose 1 (recommended } \\
\text { dose) }\end{array}\end{array}$ & $5.0 \mathrm{aA}$ & $2.7 \mathrm{bA}$ & $21.5 \mathrm{aA}$ & $27.0 \mathrm{aA}$ & $15.8 \mathrm{aA}$ & $24.3 \mathrm{abA}$ & $42.3 \mathrm{aA}$ & $54.0 \mathrm{aA}$ \\
$\begin{array}{l}\text { 5. Furrow-dose 2 (twice the rec- } \\
\text { ommended dose) }\end{array}$ & $3.0 \mathrm{aA}$ & $2.5 \mathrm{bA}$ & $20.5 \mathrm{aA}$ & $21.8 \mathrm{abA}$ & $11.8 \mathrm{aA}$ & $21.0 \mathrm{abA}$ & $37.0 \mathrm{aA}$ & $47.3 \mathrm{aA}$ \\
$\begin{array}{l}\text { 6. Furrow-dose 3 (three times the } \\
\text { recommended dose) }\end{array}$ & $24.1 \mathrm{aA}$ & $27.3 \mathrm{aA}$ & $19.0 \mathrm{aA}$ & $24.5 \mathrm{abA}$ & $46.2 \mathrm{aA}$ & $54.0 \mathrm{aA}$ \\
$\begin{array}{l}\text { 7. Furrow (dose 1 in furrow) and } \\
\text { Seed (Treatment 1) }\end{array}$ & $4.0 \mathrm{aA}$ & $1.8 \mathrm{bA}$ & $21.5 \mathrm{aA}$ & $16.5 \mathrm{bA}$ & $16.6 \mathrm{aA}$ & $12.9 \mathrm{bA}$ & $42.3 \mathrm{aA}$ & $30.8 \mathrm{bA}$ \\
\hline
\end{tabular}

Means followed by the same uppercase letters in the lines and lowercase letters in the columns, within each variable, did not differ significantly according to the Duncan test, at $5 \%$ probability of error.

There were no significant differences between treatments in terms of TNV, with the exception of treatment 6 in the NC, which showed lower TNV values. The two soil types only differed when the inoculant was applied in the furrow and seed (treatment 7) for NP1 and in treatment 2 without inoculum for NP2. In both cases, the native cerrado soil obtained higher values than the previously cultivated soil (Table 5).

In terms of average soybean grain yield (Table 6), there was no interaction between soil and inoculant application method, differing only in the production between inoculation treatments. This indicates that application methods only slightly impact soybean yield components.

Table 6. Soybean weight average in previously cultivated and native cerrado soil (NC) gasses.

\begin{tabular}{lc}
\hline Treatment & Grain weight $(\mathbf{g}$ vessel \\
\hline
\end{tabular}

Means followed by the same letters in the columns did not differ significantly according to the Duncan test, at $5 \%$ probability of error.

*Productivity of two soybean plants per vessel. 
Soybean performance was highest when the inoculant was applied in the furrow-dose 2 (treatment 5), without, however, differences between treatments 1 (inoculant + fungicide + micronutrient via seed) and 7 (furrow + seed). Treatment 5 entailed intermediate performance to the poor in the other evaluated characteristics, especially in relation to the production of fresh and dry matter. However, lower mass accumulation did not affect productivity; similar results were observed for treatment 1 . With treatment 7 , good performance in terms of other variables was obtained, suggesting that this treatment can be a balanced alternative to soybean inoculation. Vieira Neto et al. (2008b) studied different methods of inoculant application and their effects on soybean nodulation and concluded that in a field without previous cultivation of soybeans, inoculant application associated with fungicide and micronutrient application via seed provides higher nodulation, whereas in previously cultivated areas, soybean plants responded most to the application of liquid inoculant at the planting furrow.

\section{Conclusions}

Inoculation was more effective in native cerrado soil than in soil previously cultivated with soybean.

Soybean performance in the treatments without inoculation was better in previously cultivated soil.

Inoculation of soybeans via the planting furrow is a viable technique because of the practicality of operations and the similarity of the results obtained with the traditional application via seed. In this study, the recommended dose is reflected in treatment $5\left(6.0 \mathrm{ml}\right.$ of inoculant Rhizomax ${ }^{\circledR}$ to $2 \mathrm{~L}$ water).

\section{Acknowledgements}

Financial support for this study was provided by the Foundation for Support to Research and Innovation of Espírito Santo (FAPES).

\section{References}

AHEMAD, M.; KHAN, M. S. Effect of tebuconazoletolerant and plant growth promoting Rhizobium isolate MRP1 on pea-Rhizobium symbiosis. Scientia Horticulturae, New York, v. 129, n. 2, p. 266-272, 2011.

ALBAREDA, M.; RODRÍGUEZ-NAVARRO, D. N.; CAMACHO, M.; TEMPRANO, F. J. Alternatives to peat as a carrier for rhizobia inoculants: Solid and liquid formulations. Soil Biology \& Biochemistry, Oxford, v. 40, n. 11, p. 2771-2779, 2008.

ALBINO, U. B.; CAMPO, R. J. Efeito de fontes e doses de molibdênio na sobrevivência do Bradyhrizobium e na fixação biológica de nitrogênio em soja. Pesquisa Agropecuária Brasileira, Brasília, v. 36, n. 3, p. 527-534, 2001.

CAMPO, R. J.; ALBINO, U. B.; HUNGRIA, M. Métodos de aplicação de micronutrientes na nodulação e na fixação biológica do $\mathrm{N}_{2}$ em soja. Londrina: Embrapa Soja, $1999.7 \mathrm{p}$.

CAMPO, R. J.; HUNGRIA, M. Compatibilidade do uso de inoculantes e fungicidas no tratamento de sementes de soja. Londrina: Embrapa Soja, 2000. 31 p. (Embrapa Soja. Boletim de Pesquisa, 4).

CAMPO, R. J.; HUNGRIA, M.; LAURETO, E.; MIURA, L. M.; SIBALDELLI, R. N. R.; MORAIS, J. Z.; SOUZA, M. P. Compatibilidade de aplicação de inoculantes com defensivos agrícolas e micronutrientes (04.0.94.33202). In: HOFFMANN-CAMPO, C. B.; SARAIVA, O. F. (Org.). Resultados de pesquisa da Embrapa Soja - 2002: microbiologia de Solos. Londrina: Embrapa Soja, 2003. p.2 5-38. (Documentos, 216).

CAMPO, R. J.; HUNGRIA, M.; LAURETO, E.; MIURA, L. M.; SIBALDELLI, R. N. R.; MORAIS, J. Z.; SOUZA, M. P.; OLIVEIRA, M. C. N. Compatibilidade de aplicação de inoculantes com defensivos agrícolas e micronutrientes (04.2001.340-02). In: SARAIVA, O. F. (Org.). Resultados de pesquisa da Embrapa soja - 2003: microbiologia de Solos. Londrina: Embrapa Soja, 2004. p. 45-57. (Documentos, 243).

CARVALHO, J. C.; VIECELLI, C. A.; ALMEIDA, D. K. Produtividade e desenvolvimento da cultura da soja pelo uso de regulador vegetal. Acta Iguazu, Cascavel, v. 2, n. 1, p. 50-60, 2013.

DYBING, C. D. Soybean bean flower production as related to plant growth and seed yield. Crop Science, Madison, v. 34, n. 2, p. 489-497, 1994.

EMPRESA BRASILEIRA DE PESQUISA AGROPECUÁRIA - EMBRAPA. Sistema brasileiro de classificação de solos. 3. ed. Brasília: Embrapa Produção de Informação, 2013. 353 p. 
Tecnologias de produção de soja na Região Central do Brasil 2014. Londrina: Embrapa Soja, 2013. 265 p. (Sistemas de Produção, 16).

HUANG, Y.; ZHANG, T.; ZENG, S.; CHEN, J. Policy research on agricultural non-point source water pollution control in dianchi lake area of china. In: ZHU, Z. L.; NORSE, D.; SUN, B. Policy for reducing non-point pollution from crop production in China. Beijing: China Environmental Science Press, 2006. p. 135-161.

HUNGRIA, M.; MENDES, I. C.; MERCANTE, F. M. A fixação biológica do nitrogênio como tecnologia de baixa emissão de carbono para as culturas do feijoeiro e da soja. Londrina: Embrapa Soja, 2013. 22 p. (Documentos, 337).

MASCARENHAS, H. A. A.; TANAKA, R. T.; WUTKE, E. B. Nitrogênio - soja aduba a lavoura. Revista Cultivar, Pelotas, n. 48, p. 18-20, 2003. Disponível em: <http:// www.agrolink.com.br/colunistas/nitrogenio---sojaaduba-a-lavoura----_578.html>. Acesso em: 16 jun. 2016.

MENDES, I. C.; REIS, F. B.; CUNHA, M. H. 20 perguntas e respostas sobre fixação biológica de nitrogênio. Planaltina: Embrapa Cerrados, 2010. 17 p. (Documentos, 281).

PEREIRA, C. E.; OLIVEIRA, J. A CALDEIRA, C. M.; BOTELHO, F. J. E. Efeito do tratamento das sementes de soja com fungicidas e período de armazenamento na resposta da planta inoculada com Bradyrhizobium. RevistaAgro@mbiente, Boa Vista, v. 4, n. 2, p.62-66, 2010 .
PREVOST, D.; GAUVIN-TRUDEL, C.; JUGE, C. Diversity of Bradyrhizobium populations associated to soybean-maize rotations in Québec, Eastern Canada, and their potential to improve growth of both plant species. Applied Soil Ecology, Amsterdam, v. 59, p. 29-38, 2012.

RASCIO, N.; ROCCA, N. L. Biological nitrogen fixation. In: JØRGENSEN, S. E.; FATH, B. D. Encyclopedia of ecology. Amsterdam, Netherlands: Elsevier, 2008. p. 412-419.

SIYAL, A. A.; SIYAL, A. G. Strategies to reduce nitrate leaching under furrow irrigation. International Journal of Environmental Science and Development, Singapore, v. 4, n. 4, p. 431-434, 2013.

SUN, B.; CHEN, D. L.; LI, Y.; WANG, X. X. Nitrogen leaching in an upland cropping system on an acid soil in subtropical China, lysimeter measurements and simulation. Nutrient Cycling in Agroecosystems, Dordrecht, v. 81, n. 3, p. 291-303, 2008.

TERPOLILLI, J. J.; HOOD, G. A.; POOLE, P. S. What determines the efficiency of N2-fixing rhizobium-legume symbioses? Advances in Microbial Physiology, New York, v. 60, n. 5, p. 325-389, 2012.

VIEIRA NETO, S. A.; PIRES, F. R.; MENEZES, C. C. E.; MENEZES, J. F. S.; SILVA, A. G.; SILVA, G. P.; ASSIS, R. L. Formas de aplicação de inoculante e seus efeitos sobre a nodulação da soja. Revista Brasileira de Ciência do Solo, Viçosa, v. 32, n. 2, p.861-870, 2008 b.

VIEIRA NETO, S. A.; PIRES, F. R.; MENEZES, C. C. E.; SILVA, A. G.; ASSIS, R. L.; SILVA, G. P.; MENEZES, J. F. S. Formas de aplicação de inoculante e seus efeitos na cultura da soja. Bioscience Journal, Uberlândia, v. 24, n. 2, p. 56-68, 2008a. 
